\author{
Hanna Nałęcz \\ Instytut Matki i Dziecka w Warszawie \\ hanna.nalecz@imid.med.pl \\ Anna Ostrowska-Tryzno \\ Anna Pawlikowska-Piechotka \\ Akademia Wychowania Fizycznego w Warszawie \\ Wydział Turystyki i Rekreacji \\ anna.tryzno@awf.edu.pl \\ anna.piechotka@gmail.com
}

\title{
SIŁOWNIE PLENEROWE JAKO PRZYKŁAD OUTDOOROWEJ AKTYWNOŚCI REKREACYJNEJ NA TERENACH ZURBANIZOWANYCH
}

\begin{abstract}
Abstrakt: Siłownie plenerowe stają się w miastach europejskich coraz powszechniejsze i stanowią nowy element ich infrastruktury w miejscach rekreacji i sportu. Lokalizowane są w parkach miejskich, osiedlach mieszkaniowych, przy terenach sportowych czy szkołach. Ustawione w tego typu obiektach urządzenia są przeznaczane najczęściej dla osób starszych lub z niepełnosprawnością. Celem autorek artykułu było przeprowadzenie analizy użytkowania siłowni plenerowych, znajdujących się w Warszawie oraz okolicznych miejscowościach.
\end{abstract}

Słowa kluczowe: sport dla wszystkich, infrastruktura sportowo-rekreacyjna, siłownie plenerowe, outdoorowa aktywność rekreacyjna, rekreacja w mieście.

\section{WPROWADZENIE}

Nie jest zaskoczeniem, że mieszkańcy miast mają obecnie coraz wyższe oczekiwania nie tylko w stosunku do jakości mieszkań, ale i do otoczenia budynków, $\mathrm{w}$ tym terenów rekreacyjno-sportowych w pobliżu miejsca zamieszkania. Rośnie świadomość znaczenia przestrzeni publicznej osiedli i zainteresowanie możliwościami jej wykorzystania w czasie wolnym. Mieszkańcy poszukują możliwości wypoczynku w środowisku zdrowym, estetycznym, znajdującym się blisko domu, wyposażonym $\mathrm{w}$ atrakcyjne urządzenia terenowe, pozwalające na podejmowanie różnorodnych form rekreacji, dostosowanych do wieku, kondycji fizycznej i zainteresowań. Swoje potrzeby coraz częściej zgłaszają w projektach składanych w ramach budżetu partycypacyjnego ${ }^{1}$.

Miejskie tereny otwarte, odpowiednio przygotowane pod względem infrastruktury sportowej i rekreacyjnej, zadbane i estetyczne, otoczone pielęgnowaną zielenią i dostępne dla lokalnej społeczności jako miejsce podejmowania codziennej aktywności fizycznej, są istotnym elementem programu „Sport dla wszyst- kich". Program ten jest upowszechniany w wielu krajach unijnych, m.in. w ramach kampanii Vital City (Zdrowe Miasto), która ma na celu propagowanie zdrowego stylu życia oraz zachęcenie do podejmowania aktywności fizycznej na terenach zieleni o wysokiej jakości środowiska - European Commission Vital City Project CORDIS 2010-2014 (www.cordis.europa. eu 2014).

W myśl polskich przepisów obowiązek tworzenia terenów rekreacyjno-sportowych i utrzymywania ich w dobrym stanie spoczywa na samorządach gminnych (Ustawa $z$ dnia 8 marca 1990 r. o samorzadzie gminnym - DzU 1990, nr 16, poz. 95), a opieka nad terenami wypoczynku osiedlowego jest zadaniem administracji lub wspólnoty mieszkaniowej. Nie ma jednak obecnie zarządzeń ani normatywu urbanistycznego, które jednoznacznie określałyby minimalną powierzchnię oraz sposób urządzenia tego typu obiektów (w obowiązującej ustawie Prawo budowlane z roku 2003 nie zostało omówione to zagadnienie). Ogólne zalecenia są zawarte jedynie w Rozporzadzeniu Ministra Infrastruktury 
z 12 kwietnia 2002 r. w sprawie warunków technicznych, jakim powinny odpowiadać budynki i ich usytuowanie (dział II, rozdział 8), w którym jest mowa o konieczności przeznaczenia $25 \%$ terenu inwestycji budownictwa mieszkaniowego wielorodzinnego na powierzchnie biologicznie czynne, urządzone pod kątem rekreacji mieszkańców (Rozporządzeniu Ministra Infrastruktury z 12 kwietnia 2002 r. w sprawie warunków technicznych, jakim powinny odpowiadać budynki i ich usytuowanie, DzU 2002, nr 75, poz. 690).

W Polsce po zakończeniu II wojny światowej obowiązywał normatyw urbanistyczny (zniesiony w 1994 r.), określający m.in. wielkość terenów rekreacyjnych w zespołach mieszkaniowych wielorodzinnych. Tak zwany wskaźnik urbanistyczny nie był sztywny, w okresie powojennym ulegał kilkakrotnym modyfikacjom. W zależności od okresu wprowadzenia, zgodnie z tym wyznacznikiem, na mieszkańca osiedla powinno przypadać 8-15 $\mathrm{m}^{2}$ terenów zieleni. W niektórych okresach za pomocą wskaźnika urbanistycznego opisywano także obowiązujący sposób urządzenia terenów zieleni oraz narzucano minimalny program niezbędnej infrastruktury sportowo-rekreacyjnej na osiedlach mieszkaniowych.

Obecnie, zgodnie z zaleceniami Unii Europejskiej dla krajów członkowskich (European Green Infrastructure Strategy), wskaźnik wynosi $40 \mathrm{~m}^{2}$ terenów zieleni na mieszkańca miasta, w tym $26 \mathrm{~m}^{2}$ terenów urządzonych odpowiednio do odpoczynku aktywnego (EU Comission 2013). Należy podkreślić, że są to wskaźniki zbliżone do zaleceń wydawanych od 200 lat przez urbanistów i lekarzy. Takie zapisy pojawiały się w niemieckich, francuskich, angielskich i austriackich planach urbanistycznych już w XIX w. (OsTROWSKI 1975, 2001, TOŁWIŃSKI 1963, WEJCHERT 2008). Jakościową zmianę warunków życia Brytyjczyków miała przynieść koncepcja urbanistyczna „miasta ogrodu” (garden city), proponowana przez Ebenezera Howarda. Pierwsze miasto ogród (Letchworth) powstało w roku 1903. Centralną część miasta przeznaczano na tereny zieleni, dostępne dla mieszkańców jako miejsca wypoczynku i rekreacji. Koncepcja garden city szybko zyskała popularność w innych krajach europejskich, także w Polsce (TYSZKA 2012). Obecnie zauważalny jest renesans idei garden city, stanowiącej przykład zrównoważonego rozwoju miast w ujęciu ekologicznym i zdrowotnym.

Zgodnie ze współczesnymi zaleceniami badaczy przedmiotu (PIĄTKOWSKA i in. 1976, WIRSZYŁŁO 1982, KorZENIEWSKI 1989, CERVER 1992, DALy 2000, BALE 2001, CHMIELEWSKI 2002, STUTZERBACHER i ULRICH 2002, CHEISURA 2004, MAAS 2006, SAWYER 2006, WEJCHERT 2008, RZEGOCIŃSKA-TYŻUK 2010, VAN DER BERG 2010, LEE 2011, UjMA-WĄSOWICZ 2012, PAWLIKOWSKA-PIECHOTKA 2015), a także z rekomendacjami unijnymi (EU Comission 2013) w miastach powinno się za- pewniać istnienie terenów o programie rekreacyjno-sportowym na trzech poziomach:

- elementarnym (osiedlowym) - w strefie przydomowej (położone w odległości do $100 \mathrm{~m}$ od miejsca zamieszkania), urządzone $\mathrm{z}$ myślą o rekreacji młodzieży i dorosłych, a także o placach zabaw dla dzieci; rekomendowany wskaźnik zapotrzebowania terenu: 10-12 m² na 1 mieszkańca osiedla;

- podstawowym (dzielnicowym) - na terenie osiedla lub dzielnicy (położone $\mathrm{w}$ promieniu 500-1000 m od miejsca zamieszkania), urządzone w celu realizacji bogatego programu zabaw dla dzieci (z uwzględnieniem różnych grup wiekowych), mające urozmaicony program rekreacyjno-sportowy dla młodzieży i dorosłych, wypoczynek osób starszych; rekomendowany wskaźnik zapotrzebowania terenu: 10-12 $\mathrm{m}^{2}$ na 1 mieszkańca dzielnicy;

- ponadpodstawowym (ogólnomiejskim) - na terenie dzielnicy, na jej obrzeżach lub poza dzielnicą (położone ponad $1000 \mathrm{~m}$ od miejsca zamieszkania), tereny sportowo-wypoczynkowe (tematyczne, wyposażone w urządzenia specjalistyczne), parki i ogrody dydaktyczne; rekomendowany wskaźnik zapotrzebowania terenu: $12 \mathrm{~m}^{2}$ na 1 mieszkańca miasta.

Wymienione trzy podstawowe segmenty sumują się pod względem wskaźników powierzchni terenów sportowo-rekreacyjnych przypadających na 1 mieszkańca $\left(12 \mathrm{~m}^{2}+12 \mathrm{~m}^{2}+12 \mathrm{~m}^{2}\right)$, dając w efekcie powierzchnię $36 \mathrm{~m}^{2}$ terenów zieleni miejskiej na 1 mieszkańca, bliską standardom urbanistycznym, rekomendowanym przez wytyczne Unii Europejskiej. Wyróżnione poziomy narzucają nie tylko lokalizację, powierzchnię, ale i program - podstawowy w strefie elementarnej i bogaty, różnorodny na poziomie dzielnicy i miasta.

Znaczący wpływ na popularność i dobre funkcjonowanie terenów sportu i wypoczynku ma wybór lokalizacji, różnorodna i zadbana zieleń, dobór i racjonalne rozmieszczenie obiektów i urządzeń sportowych. Ważne jest wprowadzanie urozmaiconych i nowoczesnych urządzeń - dla przełamania monotonii i podniesienia atrakcyjności miejsca. Wszystkie wymienione czynniki są istotne i determinują jakość przestrzenną terenów rekreacyjno-sportowych oraz umożliwiają codzienną aktywność rekreacyjną mieszkańców, mających zróżnicowane preferencje i swoje ulubione zajęcia (KOZDROŃ 2008, MOGIŁA-LISOWSKA 2010, MORGULEC-ADAMOWICZ i in. 2015).

Celem niniejszych badań było przeprowadzenie analizy charakteru użytkowania siłowni plenerowych, zlokalizowanych na obszarze Warszawy oraz w okolicznych miejscowościach. Badania terenowe, obejmujące siłownie plenerowe jako nowe elementy infrastruktury w miejscach rekreacji i sportu w mieście, prowadzono $\mathrm{w}$ ramach projektów badawczych ds.-114 oraz ds. $-300^{3}$, zrealizowanych w AWF w Warszawie. 
Zgodnie z założeniami metodologicznymi badania w terenie polegały na obserwacjach uczestniczących i nieuczestniczących jawnych, notatkach strukturalizowanych z wizji lokalnej według ujednoliconego kwestionariusza oraz wywiadach strukturalizowanych, również według ujednoliconej ankiety.

\section{SIŁOWNIE PLENEROWE - NOWY ELEMENT FUNKCJONALNO- -PROGRAMOWY ZAGOSPODAROWANIA TERENÓW SPORTU I REKREACJI W MIEŚCIE}

W kwestii szczegółów funkcjonalno-programowych zagospodarowania terenów sportu i wypoczynku, pożądanych urządzeń i obiektów - nie ma jednego uniwersalnego zalecenia. Po pierwsze każdy z trzech poziomów (elementarny, podstawowy, ponadpodstawowy) wymaga innego programu, powierzchni i urządzeń. Po drugie każda społeczność (osiedlowa, miejska) jest inna i różni się pod względem stylu życia, upodobań i oczekiwań wobec terenów sportu i wypoczynku. Ponadto zarządzający terenami rekreacji osiedlowej i ich organizatorzy mają różne uwarunkowania terenowe i ekonomiczne, wpływające na możliwości realizacji konkretnego zagospodarowania urządzeń.

Z uogólnionych zaleceń dotyczących dzielnicowych i ogólnomiejskich terenów sportu i wypoczynku wynikają dużo większe możliwości zagospodarowania tych miejsc niż zieleńców osiedlowych. Zgodnie z owymi wytycznymi tworzone są boiska do różnego rodzaju gier zespołowych, korty tenisowe, tereny do ćwiczeń gimnastycznych, place do gry w kręgle, bule, kometkę, miejsca do ćwiczeń łuczniczych i gimnastycznych, do jogi, pola do minigolfa, place zabaw dla dzieci, ścieżki do ćwiczeń, kąpieliska, plaże, miejsca piknikowe, górki saneczkowe, ośle łączki do wprawek narciarskich, małe zagajniki z alejkami spacerowymi oraz trasami do jazdy rowerowej i konnej. Przy dzielnicowych lub ogólnomiejskich terenach sportowo-rekreacyjnych znajdują się często kluby sportowe, w których użytkownicy mają możliwość uczestniczenia $\mathrm{w}$ zorganizowanych zajęciach oraz wypożyczenia sprzętu (np. porty żeglarskie, zespoły kąpielisk, zagospodarowane stoki do jazdy na nartach). Koncepcje wypoczynku w mieście z upływem kolejnych dekad ulegają naturalnie przeobrażeniom, wobec czego założenia programowe dotyczące urządzeń rekreacyjnych, ich doboru oraz standardów powinny być aktualizowane i udoskonalane.

Od kilku lat rośnie popularność zielonych siłowni (plenerowych, terenowych, zewnętrznych - nie osią- gnięto jeszcze jednomyślności co do nazwy), w których urządzenia do ćwiczeń ustawiane są na terenach otwartych (na skwerach, w parkach miejskich, miejskich ośrodkach sportu i wypoczynku, na zieleni osiedlowej). Warunkiem powodzenia inwestycji jest jej dostępność (dobrze skomunikowany teren publiczny), atrakcyjność otoczenia oraz różnorodność i jakość przyrządów do ćwiczeń.

Zielone siłownie (siłownie plenerowe) w polskich miastach zajmują najczęściej niewielką powierzchnię (około 100-200 m²), wydzieloną z trawiastego skweru osiedlowego lub parku miejskiego. Do najpopularniejszego wyposażenia zielonych siłowni należą stepper, wioślarz, rower stacjonarny, piechur, narty, biegacz, przyrządy do ćwiczenia równowagi oraz orbitreki².

Lokalizacja tego typu obiektów jest niezmiernie ważna z punktu widzenia walorów użytkowych. $\mathrm{Na}$ przykład w Warszawie zielone siłownie są budowane w miejscach wybranych w czasie konsultacji społecznych (w latach 2013-2017 powstawały w ramach akcji "Warszawa w dobrej kondycji”). Obecnie jest ich ponad 150 i przez cały czas powstają kolejne. Docelowo w stolicy ma być ponad 200 siłowni plenerowych, zlokalizowanych w różnych dzielnicach i przystosowanych do potrzeb osób o zróżnicowanym stopniu sprawności fizycznej (www.sportowa.warszawa.pl). Wszystkie są zunifikowane i składają się z urządzeń do ćwiczeń, w większości znanych z siłowni klasycznych, ale skonstruowanych $\mathrm{w}$ taki sposób i z takich materiałów, by nie uległy zniszczeniu w różnych warunkach pogodowych (deszcz, grad, śnieg, letnie upały i silna insolacja). Charakterystyczne żółto-czerwone ostre barwy, stanowiące jasny sygnał obecności zielonej siłowni w przestrzeni publicznej, przyciągają wzrok i są już znane mieszkańcom miasta. Przy każdym z urządzeń (np. przy orbitreku, wahadle, biegaczu, wioślarzu, twisterze) znajdują się czytelne tablice informacyjno-instruktażowe. Zamieszczone na nich piktogramy oraz teksty umożliwiają użytkownikom o różnym stopniu obycia $\mathrm{z}$ takimi urządzeniami prawidłowe korzystanie $\mathrm{z}$ nich.

\section{SIŁOWNIE PLENEROWE I ICH UŻYTKOWNICY - REZULTATY BADAŃ TERENOWYCH}

Badania terenowe dotyczące siłowni plenerowych jako nowego elementu infrastruktury na terenach rekreacji i sportu $\mathrm{w}$ mieście prowadzono $\mathrm{w}$ ramach projektów badawczych ds.-114 oraz ds.-300, zrealizowanych w AWF w Warszawie w dwóch etapach - w latach 2014-2015 (badaniami objęto wówczas tylko siłownie w Warszawie, znajdujące się w dzielnicach Bielany, Ursynów 
i Żoliborz) oraz w latach 2016-2017 (ankiety przeprowadzono w kilkudziesięciu siłowniach w Warszawie i w regionie Mazowsza).

W niniejszym artykule zaprezentowano rezultaty drugiego etapu badań, tj. wnioski z badań terenowych, przeprowadzonych w semestrach wiosennych (kwiecień-czerwiec) w roku 2016 i 2017, w ramach obozu naukowego, stanowiącego część seminarium magisterskiego, z udziałem studentów I roku studiów drugiego stopnia na Wydziale Turystyki i Rekreacji AWF Józefa Piłsudskiego w Warszawie.

Zgodnie z obranymi metodami badawczymi badania $\mathrm{w}$ terenie, prowadzone codziennie (również w weekendy i dni świąteczne) w godzinach 10.00-18.00, polegały na obserwacjach uczestniczących i nieuczestniczących jawnych, tworzeniu notatek strukturalizowanych z wizji lokalnej i wywiadach strukturalizowanych, według ujednoliconego kwestionariusza ankiety, przeprowadzonych tylko z dorosłymi użytkownikami po poinformowaniu ich o celu badań.

Materiałem do badań terenowych w tym okresie było 49 wybranych siłowni plenerowych - obiektów położonych w różnych dzielnicach Warszawy oraz w wybranych miejscowościach województwa mazowieckiego. Większość z badanych obiektów znajdowała się w parkach miejskich (25 siłowni plenerowych) lub na skwerach osiedlowych (22 siłownie plenerowe), jedna na terenie uczelni (AWF w Warszawie) oraz jedna na terenie OSiR - Ośrodka Sportu i Rekreacji (pływalnia "Orka" w Sochaczewie). W miejscowościach pozawarszawskich badaniami objęto siłownie plenerowe położone w Grodzisku Mazowieckim (3 obiekty), Konstancinie (1 obiekt), Milanówku (2 obiekty), Mińsku Mazowieckim (1 obiekt), Modlinie (2 obiekty), Nowym Dworze (2 obiekty), Ożarowie Mazowieckim (1 obiekt), Sochaczewie (2 obiekty) i Żyrardowie (1 obiekt). W Warszawie badania przeprowadzono na terenie następujących dzielnic: Bemowo (1 obiekt), Białołęka (2 obiekty), Bielany (4 obiekty), Mokotów (3 obiekty), Ochota (4 obiekty), Praga-Południe (4 obiekty), Praga-Północ (3 obiekty), Ursus (4 obiekty), Ursynów (1 obiekt), Wola (2 obiekty), Włochy (4 obiekty), Żoliborz (2 obiekty). W rezultacie badania terenowe przeprowadzono w 15 obiektach położonych w miejscowościach pozawarszawskich, znajdujących się na terenie Mazowsza, oraz w 34 obiektach zlokalizowanych w Warszawie (por. tab. 1). Podstawą do takiego wyboru materiału do badań było założenie, że należy uwzględnić w nich stosunkowo szeroki przekrój kulturowo-społeczny oraz odmienne uwarunkowania dostępu do infrastruktury sportowo-rekreacyjnej dla miejscowej społeczności, co pozwalało na uzyskanie $\mathrm{w}$ miarę obiektywnych wyników i wysunięcie wniosków końcowych z materiału dość reprezentatywnego, ponieważ uzyskanego z bardzo różnorodnych lokalizacji i kręgów społecznych.
Wywiadami strukturalizowanymi (ujednolicony kwestionariusz) objęto tylko osoby dorosłe, które przebywały $\mathrm{w}$ czasie badań na terenie obiektu oraz zostały poinformowane o celu projektu i wyraziły zgodę na uczestniczenie $\mathrm{w}$ ankiecie. Pozyskano $\mathrm{w}$ ten sposób 100 wypełnionych anonimowo kwestionariuszy (badania face to face, in situ) ${ }^{4}$. W jednym badanym obiekcie przeprowadzano przeciętnie dwa wywiady. Niestety w kilku odwiedzanych siłowniach ćwiczący stanowczo odmówili wzięcia udziału w sondażu diagnostycznym, ale za to zdarzało się też, że w innych obiektach wszyscy użytkownicy, którzy tam przebywali, zgodzili się udzielić wywiadu.

Badania siłowni plenerowych na terenie Warszawy i regionu Mazowsza przeprowadzono, wykorzystując następujące metody:

- obserwacje uczestniczące i nieuczestniczące jawne, notatki strukturalizowane według ujednoliconego kwestionariusza (wzór A1), dokumentacja fotograficzna (za zgodą użytkowników obiektu);

- wywiady anonimowe z użytkownikami, strukturalizowane i semistrukturalizowane, przeprowadzone in situ, face to face, według ujednoliconego kwestionariusza (wzór B1), oraz nieformalnych rozmów rozszerzających zakres pytań o spontanicznie pojawiające się wątki tematyczne (brały w nich udział tylko osoby dorosłe, po wyjaśnieniu im celu badań i uzyskaniu od nich zgody).

$\mathrm{Z}$ tak przeprowadzonych badań terenowych wynika, że na siłowniach plenerowych ćwiczy zdecydowanie więcej kobiet (65\%) niż mężczyzn (35\%). Są to osoby w różnym wieku, od 7 lat (najmłodszy użytkownik, chłopiec w towarzystwie ojca) do 72 lat (najstarszy użytkownik, kobieta). Z obserwacji i deklaracji składanych w czasie wywiadów wiadomo, że użytkownikami badanych siłowni plenerowych są najczęściej osoby starsze, powyżej 50-60 roku życia, które traktują ćwiczenia jako przyjemność, aktywność dla zdrowia. Część użytkowników ćwiczy ze względu na zalecenia lekarskie, kontynuując (także uzupełniając) zajęcia rehabilitacyjne, w których uczestniczyli lub uczestniczą w ramach NFZ lub prywatnej opieki medycznej.

Jeżeli siłownia plenerowa jest zlokalizowana w pobliżu szkoły podstawowej lub gimnazjum (obiekty położone w Sochaczewie oraz w Warszawie na Ursynowie), w trakcie roku szkolnego, wczesną jesienią i późną wiosną, najczęściej w czasie dużej przerwy, ćwiczą tam także uczniowie (przeważnie chłopcy w wieku 10-14 lat, rzadziej dziewczęta).

W wybranych do badań obiektach nie zauważono istotnych różnic w programie funkcjonalno-użytkowym, estetyce, zieleni, stanie technicznym i doborze urządzeń, dbałości o stan sanitarny obiektu, a także nie odnotowano różnic w przekroju demograficznym użyt- 
kowników i preferowanych przez nich ćwiczeniach - zarówno w przypadku siłowni położonych w różnych dzielnicach Warszawy, jak i zlokalizowanych w miejscowościach poza stolicą (por. tab. 1).

Objęte badaniami siłownie plenerowe składają się najczęściej z kilku urządzeń, do wyjątków należy siłownia, na której znajduje się więcej niż 8-10 przyrządów do ćwiczeń. Najczęściej montowane to: biegacz, orbitrek, twister, krzesło, wioślarz, stepper, poręcze, ławka, drążek, narty, drabinki, prostownik, rower i motyl. Wciąż do rzadkości należy instalowanie ścianki wspinaczkowej, trampoliny, surfera, prasy nożnej, pajacyka czy koła tai-chi. Tylko jeden obiekt (siłownia plenerowa na terenie osiedla mieszkaniowego na warszawskich Bielanach) był wyposażony w zestaw do ćwiczeń „Herkules”.

Podłożem, na którym są ustawione urządzenia w siłowni plenerowej, jest najczęściej trawa lub piasek, rzadziej wykładzina syntetyczna. Takie siłownie mają zazwyczaj powierzchnię 100-200 $\mathrm{m}^{2}$ (najmniejszy z obiektów objętych badaniem, zlokalizowany w par$\mathrm{ku}$ Cytadela w Warszawie, zajmuje obszar około $50 \mathrm{~m}^{2}$ ). Siłownie bywają ogrodzone (np. na terenie AWF w Warszawie - metalową siatką), ale większość tego typu obiektów położonych na terenie skwerów osiedlowych lub w parkach miejskich - nie jest wygrodzona (np. w warszawskim parku Cytadela, parku Kępa Potocka).

Stan techniczny urządzeń jest na ogół bardzo dobry, a teren otoczony zielenią, zadbany i czysty. Żadna z objętych badaniem siłowni plenerowych nie ma toalety i własnego oświetlenia. Oświetlenie jest najczęściej pośrednie - światło pada z pobliskich latarni, znajdujących się w parku miejskim lub w osiedlu, co nie zawsze daje możliwość ćwiczenia po zmroku. Na terenie wszystkich badanych obiektów są kosze na odpady (por. tab. 1). Informacja o regulaminie znajduje się w widocznym miejscu, tablice nt. zasad korzystania z przyrządów do ćwiczeń mocowane są na poszczególnych urządzeniach.

Tylko siłownia plenerowa na terenie AWF w Warszawie, przy ulicy Marymonckiej 34, jest połączona z placem zabaw. Należy podkreślić, że w czasie badań terenowych wielu ankietowanych zwracało uwage na potrzebę zamontowania dodatkowych urządzeń na siłowni, przeznaczonych dla najmłodszych (dzięki temu rodzice mogliby ćwiczyć wspólnie z dziećmi, dziadkowie $\mathrm{z}$ wnukami itp.).

Wyraźnie zaobserwowano, że w zależności od wieku i płci użytkownicy preferują korzystanie z różnych przyrządów w zielonej siłowni. Najpopularniejsze urządzenia wśród kobiet to stepper i orbitrek, a wśród mężczyzn - ławka. Młodzież chętnie korzysta z batutów i ścianek wspinaczkowych. Rowery są jednakowo popularne wśród kobiet i mężczyzn w każdym wieku. Wśród deklarowanych w ankiecie ulu- bionych urządzeń wymieniono: ławkę, „fotel rzymski”, stepper, orbitrek, rower, wyciskacz oraz wioślarza (należy przy tym podkreślić, że rower i wioślarz to także urządzenia wymieniane przez kilku badanych jako nielubiane i omijane). Przeprowadzone obserwacje potwierdzają, że faktycznie są to przyrządy klasyczne, najczęściej występujące w zestawie, najpopularniejsze i najbardziej oblegane. Zauważono, że użytkownicy siłowni na osiedlach i w parkach miejskich w Warszawie i poza nią mają różne ulubione urządzenia i formy ćwiczeń (por. tab. 1).

Czas poświęcany na ćwiczenia na jednym urządzeniu wynosi średnio około 5 minut, nieco dłużej użytkownicy pozostają na rowerze i ściance wspinaczkowej - do 10-15 minut.

Ze względu na trenowanie na obiekcie w różnych porach roku wielu odwiedzających zdejmuje do ćwiczeń ubranie wierzchnie, ale $\mathrm{z}$ powodu braku ławeczek odkłada je na trawę lub odwiesza na urządzenie, z którego nikt akurat nie korzysta. Rowery, którymi użytkownicy przyjeżdżają na siłownię, są najczęściej opierane o drzewo lub układane na trawie. Około 45\% ankietowanych (przeważnie młode kobiety i młodzi mężczyźni) ma specjalny strój do ćwiczeń (buty, spodnie lub szorty, koszulka, czapka i okulary słoneczne), pozostałe osoby (i kobiety, i mężczyźni) ćwiczą w wygodnym, codziennym ubraniu, w którym wychodzą na spacer. Najczęściej starsi użytkownicy przychodzą na siłownię samotnie, osoby młode natomiast - w parach, lub nawet $\mathrm{w}$ kilkuosobowych grupach (dzieci i młodzież z pobliskiej szkoły).

Korzystający z siłowni młodzi ludzie mają często przy sobie wodę lub napoje energetyczne, rzadziej przekąski. Osoby starsze (powyżej 50-60 lat) raczej nie przynoszą ze sobą ani napojów, ani jedzenia.

Najczęściej użytkownicy zielonej siłowni odwiedzają obiekt systematycznie, 2-3 razy w tygodniu, i ćwiczą około 15-20 minut na 3-4 ulubionych urządzeniach.

Uczestnicy wywiadów deklarują, że wyjście na siłownię plenerową łączą przeważnie ze spacerem lub bieganiem (74\% ankietowanych) oraz z jazdą na rowerze (15\% respondentów). Zdecydowanie rzadziej przyjeżdżają samochodem (2\% osób biorących udział w ankiecie) lub środkami komunikacji miejskiej (9\% rozmówców). Odległość przystanku MZK od siłowni plenerowej wynosi od $30 \mathrm{~m}$ (park Kaskada w Warszawie) do 500 m (park Cytadela w stolicy). Przy tego typu obiektach są miejsca do parkowania (w odległości 10-200 m).

Zgodnie z deklaracjami uzyskanymi w czasie wywiadów izochrona siłowni plenerowej od stałego miejsca zamieszkania wynosi najczęściej 15-20 minut spacerem, 5-10 minut jazdy na rowerze lub środkami komunikacji miejskiej, 3-5 minut jazdy samochodem. 
Ćwiczący odwiedzają zieloną siłownię najczęściej wiosną, latem i wczesną jesienią, zazwyczaj gdy jest bezdeszczowo i słonecznie. $W$ dni powszednie siłownie plenerowe są szczególnie oblegane koło południa oraz w godzinach wczesnopopołudniowych i wieczornych (późną wiosną i latem nawet do godziny 20.00-21.00), bez względu na dzień tygodnia. W czasie weekendów i świąt liczba korzystających gwałtownie rośnie - od wczesnych godzin porannych tworzą się kolejki do urządzeń na wielu atrakcyjnie położonych obiektach. Siłownie plenerowe nie są odwiedzane w czasie, gdy panują ekstremalne temperatury, tj. w mroźne dni zimowe lub upalne dni letnie (wówczas ludzie korzystają z tych obiektów sportowych dopiero wieczorem, po zachodzie słońca).

Najczęściej wymienianymi (85\% ankietowanych) codziennymi formami sportu i rekreacji poza siłownią plenerową są: spacer, spacer z psem, bieganie i szybkie marsze oraz jazda na rowerze. Około 15\% respondentów deklarowało także udział w zajęciach zorganizowanych, takich jak: fitness, trening na siłowni w klubie, jazda na rolkach i wrotkach, korzystanie z pływalni (osoby młode i w średnim wieku) oraz nordic walking (osoby starsze).

Ponad 60\% respondentów nie widziało konieczności wprowadzania jakichkolwiek zmian na odwiedzanej siłowni. Wśród sugestii dotyczących ulepszeń (wyrażonych przez 33 ankietowanych) przeważały następujące propozycje:

- ustawienie ławek w pobliżu urządzeń (nie ma gdzie odkładać toreb i zdejmowanych ubrań wierzchnich, które w związku z tym są kładzione najczęściej na ziemi i mogą się zamoczyć lub ubrudzić); z uwagi na bezpieczeństwo ławki powinny znajdować się blisko przyrządów do ćwiczeń i być z nich widoczne;

- ustawienie toalet (tam, gdzie ich brakuje) oraz systematyczne wymienianie ich i czyszczenie;

- montaż stojaków na rowery;

- wprowadzenie bardziej urozmaiconych urządzeń, ambitnych i nowoczesnych, np. elementów street workout (cytując wypowiedź jednej z ankietowanych osób: „ostatnich nowinek w tym zakresie”), umożliwiających większe obciążenia (młodzi mężczyźni), jednak jednocześnie były także postulaty zachowania urządzeń klasycznych, które wszyscy znają i lubią (cytując wypowiedź jednego z ankietowanych: „Moja dziewczyna nienawidzi nowinek, woli to, co dobrze zna - inaczej łatwo się zniechęca, a przecież chcemy ćwiczyć razem");

- zwiększenie liczby urządzeń na terenie obiektu, nawet dublowanie tych najbardziej popularnych, a w zamian likwidowanie nielubianych, które zajmują cenne miejsce (cytując jednego $\mathrm{z}$ ankietowanych: „Do lubianych ustawiają się kolejki, mało popularne są omijane i rdzewieją, niepotrzebne nikomu"),

- oświetlanie terenu po zmroku, co zwiększy bezpieczeństwo, odstraszy chuliganów i osoby naduży- wające alkoholu, a jednocześnie wydłuży czas korzystania z siłowni;

- wprowadzenie stałych patroli (ochrona, straż miejska, policja) oraz instalacja monitoringu - kamer telewizji bezprzewodowej - co zwiększy bezpieczeństwo kobiet, szczególnie w godzinach wieczornych, oraz będzie działać odstraszająco na osoby nadużywające alkoholu (teren siłowni często jest zaśmiecony butelkami pozostającymi po libacjach alkoholowych, odbywających się tam poprzedniego wieczoru);

- zwiększenie liczby siłowni plenerowych na terenie dzielnicy/w miejscowości;

- lepsze przemyślenie lokalizacji - zazwyczaj w dzielnicy są takie siłownie, na których rzadko kto bywa, oraz takie, które są bardzo popularne, a w rezultacie nadmiernie obciążone $\mathrm{w}$ atrakcyjnych porach (popołudnie i wieczór, weekendy i święta);

- wprowadzenie dni i godzin konsultacji z instruktorem - wielokrotnie zwracano uwagę na osoby ćwiczące nieświadomie w sposób dla siebie niebezpieczny $^{5}$;

- zadaszenie urządzeń, dzięki czemu możliwe będzie wykonywanie ćwiczeń w dni bardzo upalne (pod wpływem wysokich temperatur metalowe części przyrządów bardzo się nagrzewają, uniemożliwiając ich użytkowanie) oraz podniesie się komfort korzystania z siłowni w czasie deszczu;

- różne sprzeczne rozwiązania związane z roślinnością znajdującą się przy siłowniach - z jednej strony ankietowani zaznaczają, że należy wyciąć krzewy i nisko zwieszające się gałęzie, aby zredukować zagrożenie kleszczami, a z drugiej - proponują, by zwiększyć liczbę zadrzewień, drzew i krzewów w celu poprawy mikroklimatu, redukcji hałasu i zanieczyszczeń, ochrony przed wiatrem i słońcem, a także podniesienie estetyki miejsca;

- łączenie siłowni z placem zabaw dla dzieci (cytując osobę biorącą udział w ankiecie: „Aby dzieci mogły się bezpiecznie bawić, a opiekunowie w tym samym czasie spokojnie ćwiczyć") i ogradzanie takich obiektów ze względów bezpieczeństwa5;

- konieczność lepszej promocji siłowni plenerowych oraz wstawiania znaków informacyjnych (cytując mieszkańca dzielnicy Włochy: „Większość mieszkańców naszego osiedla nawet nie wie o siłowni. Że ją zbudowano. Gdzie się znajduje").

\section{PODSUMOWANIE}

Siłownie plenerowe stają się coraz powszechniejsze zarówno w miastach europejskich, jak i poza Europą (CHOW 2013, ScOTT i in. 2015)6. Takie obiekty są budowane w parkach miejskich, na osiedlach, przy terenach sportowych szkół średnich (comprehensive) m.in. 
Tab. 1. Charakterystyka zbiorcza badanych siłowni plenerowych z uwzględnieniem dwóch najbardziej typowych lokalizacji - osiedla mieszkaniowego lub parku miejskiego ${ }^{7}$

\begin{tabular}{|c|c|c|c|c|}
\hline $\begin{array}{c}\text { Urządzenia i wyposażenie } \\
\text { siłowni }\end{array}$ & $\begin{array}{c}\text { Siłownie na terenie osie- } \\
\text { dli w Warszawie } \\
\text { (16 obiektów) }\end{array}$ & $\begin{array}{c}\text { Siłownie w parkach } \\
\text { miejskich w Warszawie } \\
(17 \text { obiektów })\end{array}$ & \begin{tabular}{|c|}
$\begin{array}{c}\text { Siłownie na terenie } \\
\text { osiedli poza Warszawą } \\
\text { (8 obiektów) }\end{array}$ \\
\end{tabular} & $\begin{array}{l}\text { Siłownie na terenie par- } \\
\text { ków miejskich poza } \\
\text { Warszawą ( } 6 \text { obiektów) }\end{array}$ \\
\hline Ogrodzenie & $\begin{array}{c}\text { Na terenie wygrodzo- } \\
\text { nych osiedli } \\
\text { (metalowa siatka) }\end{array}$ & $\begin{array}{l}\text { Niewygrodzone, } \\
\text { nie zawsze też park } \\
\text { jest ogrodzony }\end{array}$ & $\begin{array}{c}\text { Na terenie wygrodzo- } \\
\text { nych osiedli } \\
\text { (metalowa siatka) }\end{array}$ & $\begin{array}{l}\text { Niewygrodzone, } \\
\text { nie zawsze też park } \\
\text { jest ogrodzony }\end{array}$ \\
\hline Podłoże & $\begin{array}{l}\text { Trawa, piasek, wykła- } \\
\text { dzina syntetyczna }\end{array}$ & Trawa, piasek & Trawa, piasek & Trawa, piasek \\
\hline Ławeczki wypoczynkowe & $\begin{array}{l}\text { Brak w pobliżu, } \\
\text { na terenie skweru } \\
\text { osiedlowego }\end{array}$ & $\begin{array}{l}\text { Brak w pobliżu, } \\
\text { na terenie parku }\end{array}$ & $\begin{array}{l}\text { Brak w pobliżu, } \\
\text { na terenie skweru } \\
\text { osiedlowego }\end{array}$ & $\begin{array}{l}\text { Brak w pobliżu, } \\
\text { na terenie parku }\end{array}$ \\
\hline Kosze na odpady & Tak & Tak & Tak & Tak \\
\hline Oświetlenie & Tak & $\begin{array}{c}\text { Nie zawsze } w \text { pobliżu } \\
\text { obiektu }\end{array}$ & Tak & $\begin{array}{c}\text { Nie zawsze } w \text { pobliżu } \\
\text { obiektu }\end{array}$ \\
\hline $\begin{array}{l}\text { CCTV, monitoring, } \\
\text { ochrona (regularne } \\
\text { patrole) }\end{array}$ & Tak & Tak & Tak & Tak \\
\hline Toaleta & Nie & Nie & Nie & Nie \\
\hline $\begin{array}{l}\text { Informacja ogólna dla } \\
\text { użytkowników in situ, } \\
\text { informacja przy przyrzą- } \\
\text { dach gimnastycznych } \\
\text { (instrukcje) }\end{array}$ & Tak & Tak & Tak & Tak \\
\hline $\begin{array}{l}\text { Oblegane, popularne } \\
\text { urządzenia }\end{array}$ & $\begin{array}{l}\text { Twister, orbitrek, } \\
\text { stepper, ławka }\end{array}$ & $\begin{array}{c}\text { Twister, ścianka } \\
\text { wspinaczkowa, ławka, } \\
\text { wahadło, stepper, rower }\end{array}$ & $\begin{array}{c}\text { Stepper, biegacz, } \\
\text { ławka }\end{array}$ & $\begin{array}{l}\text { Rower, wioślarz, } \\
\text { wyciskacz, ławka, } \\
\text { wahadło, stepper }\end{array}$ \\
\hline $\begin{array}{l}\text { Omijane, niepopularne } \\
\text { urządzenia }\end{array}$ & Rower, wioślarz & $\begin{array}{l}\text { Krzesło fit, wioślarz, } \\
\text { orbitrek }\end{array}$ & Rower, wioślarz & $\begin{array}{l}\text { Wyciąg górny, motyl, } \\
\text { koła tai-chi }\end{array}$ \\
\hline $\begin{array}{l}\text { Stan techniczny urzą- } \\
\text { dzeń }\end{array}$ & Bardzo dobry & Bardzo dobry & Bardzo dobry & Bardzo dobry \\
\hline Stan sanitarny obiektu & Bardzo dobry & Bardzo dobry & Bardzo dobry & Bardzo dobry \\
\hline
\end{tabular}

Źródło: opracowanie autorów na podstawie materiału zebranego podczas badań terenowych, przeprowadzonych w latach 2016-2017 w ramach projektu ds.-300, realizowanego w AWF Warszawa (dane uśrednione dla poszczególnych lokalizacji).

Uwaga: patrz przyp. 2.

w Berlinie, Helsinkach, Kopenhadze, Londynie, Madrycie, Sztokholmie. Niektóre z nich są przeznaczone specjalnie dla osób starszych, np. bezpłatna siłownia w Hyde Parku w Londynie, nazwana „Senior's Corner", znajdująca się przy kortach tenisowych w południowej części parku (wejście od Hyde Park Tennis Club przy Kensington Street). W wielu miastach chinskich bardzo popularne zielone siłownie zlokalizowane są nie tylko w miejskich parkach (Pekin, Kanton, Makao), ale nawet między straganami na tradycyjnym bazarze (Szanghaj). Ostatnio coraz częściej siłownie plenerowe są budowane także na pozamiejskich terenach wypoczynkowych, takich jak: plaże nadmorskie, promenady nad jeziorem, parki leśne.

Miejmy nadzieję, że również $\mathrm{w}$ polskich miastach siłownie plenerowe będą coraz powszechniejsze, a ich lokalizacja i dobór urządzeń spełnią oczekiwania lokalnej społeczności. Wyniki przeprowadzonych badań dowodzą, że tego rodzaju obiekty należą obecnie do najpopularniejszych rodzajów infrastruktury miejskich terenów zieleni. Ponadto lokalna społeczność planuje kolejne inwestycje tego typu i oczekuje ich. Ponieważ wśród zakładanych siłowni plenerowych są zarówno bardzo popularne, jak i rzadziej odwiedzane, a montowane $\mathrm{w}$ nich urządzenia można podzielić na oblegane i omijane - wydaje się, że należy wysłuchać opinii użytkowników (takich jak bardzo ważne i w wielu wypadkach słuszne uwagi przytoczone w poprzednim rozdziale) i wyciągać wnioski, aby w przyszłości te istotne dla promocji zdrowia obiekty lokalizować w sposób bardziej przemyślany, lepiej je popularyzować, a także staranniej dobierać urządzenia.

Z badań innych autorów wynika, że część mieszkańców miast, szczególnie osoby starsze, korzysta z terenów sportowo-rekreacyjnych jedynie podczas spokojnych spacerów (KOZDROŃ 2008, MOGIŁA-LISOWSKA 2010). Z tego powodu tak ważne jest stałe i konsekwentne edukowanie przedstawicieli tej grupy wiekowej w zakresie znaczenia bardziej aktywnego wypoczynku, zdrowego trybu życia i prozdrowotnych zachowań oraz podawanie rzetelnych informacji na 
temat aktualnych możliwości korzystania z infrastruktury sportowo-rekreacyjnej w pobliżu miejsca zamieszkania.

Warto podkreślić, że część postulatów została już uwzględniona przez władze miast. Przykładem do naśladowania może być realizacja programu "Aktywność w przestrzeni - siłownie plenerowe”, w którego ramach w każdej dzielnicy Warszawy wyznaczono siłownie plenerowe, gdzie odbywają się bezpłatne zajęcia $\mathrm{z}$ instruktorami.

Należy zaznaczyć, że w czasie badań terenowych w przeprowadzonych z użytkownikami siłowni plenerowych wywiadach wielokrotnie wracal temat ptrzeby zakładania uniwersalnych terenów sportu i wypoczynku, z urządzeniami atrakcyjnymi dla przedstawicieli różnych grup wiekowych - rodziców i dzieci, dziadków i wnuków - tak, aby rodziny mogły ćwiczyć razem lub po prostu blisko siebie w tym samym czasie. Zasadnicze znaczenie dla upowszechniania idei zdrowego i aktywnego trybu życia ma racjonalne urządzenie terenów sportu i wypoczynku (w tym nowych siłowni plenerowych połączonych np. z placami zabaw dla dzieci), przeznaczonych dla wszystkich, oraz zlokalizowanie tych obiektów tak, aby były łatwo dostępne na co dzień, a więc by znajdowały się w pobliżu miejsca zamieszkania użytkowników.

Z badań wynika, że siłownie plenerowe w krótkim czasie zyskały ogromną popularność, są pożyteczne, doceniane i chętnie użytkowane. Respondenci podkreślali konieczność budowania nowych obiektów oraz modernizacji i ulepszania już istniejących. Jest to ważny sygnał dla lokalnych władz, odpowiedzialnych za promocję zdrowia i jednocześnie za racjonalną politykę przestrzenną, że istnieje potrzeba zarezerwowania odpowiedniej liczby miejsc terenów otwartych, które będzie można przeznaczyć na tak ważny cel. Ankieta stała się również znakomitą okazją dla lokalnej społeczności do zasygnalizowania potrzeby takich inwestycji w projektach budżetu partycypacyjnego.

W związku z powyższym wydaje się, że wobec stałego ubytku terenów zieleni w naszych miastach ważne jest przywrócenie jednoznacznych regulacji prawnych w tym zakresie, aby określić szczegółowy normatyw dotyczący powierzchni dla terenów sportu i rekreacji przy osiedlach mieszkaniowych. Powinien obowiązywać także minimalny program funkcjonalno-użytkowy, narzucający konieczność nie tylko rezerwy terenu mogącego pełnić funkcję sportowo-rekreacyjną, ale także nakazujący racjonalne jego urządzenie. Należy bowiem podkreślić, że wprowadzanie zespołów rekreacyjno-sportowych do już istniejącej zabudowy może sprawiać trudności, jeżeli brakuje tam odpowiednich rezerw terenu przeznaczonych z góry na ten cel. Wprowadzenie rygoru normatywu powierzchni i obowiązującego programu umożliwi zakładanie i pra- widłowe zagospodarowanie uniwersalnych terenów sportu osiedlowego, spełniających oczekiwania społeczne i umożliwiających wdrażanie zasad zdrowego trybu życia oraz skuteczną popularyzację nawyków codziennej aktywności ruchowej.

\section{PRZYPISY}

1 Przykładem mogą być realizacje projektów złożonych w 2017 r., np. stworzenie siłowni plenerowej wraz z zagospodarowaniem zieleni przy skwerze Wolnej Elekcji na Woli lub na Grochowie w Warszawie oraz przy Szkole Podstawowej nr 138 w Wawrze czy rozbudowa istniejącego już obiektu przy ul. Korfantego (źródło: https:/ /app.twojbudzet.um.warszawa.pl).

2 Obecnie poszczególne przyrządy gimnastyczne funkcjonują jednocześnie pod nazwami popularnymi, nadawanymi intuicyjnie przez użytkowników, oraz handlowymi, wprowadzanymi przez różnych producentów i umieszczanymi przez nich na tablicach znajdujących się przy obiekcie oraz na konkretnych urządzeniach. Ze względu na brak ujednoliconej nomenklatury w niniejszym tekście przyjęto nazewnictwo wprowadzone przez spółkę FitPark (www.fitpark.pl).

3 Ds.-114 oraz ds.-300 - projekty badawcze realizowane w ramach działalności statutowej AWF Warszawa.

${ }^{4} \mathrm{Na}$ ten istotny aspekt bezpiecznego sposobu korzystania z przyrządów gimnastycznych zwracali także uwagę przeprowadzający badania studenci I roku studiów magisterskich AWF Warszawa, mający już wiedzę i doświadczenie, które umożliwiają dokonanie obiektywnej oceny (uwagi dwóch osób w kwestionariuszu A1, część: „Obserwacje i notatki ankietera in situ, w czasie wizji lokalnej $\mathrm{w}$ badanym obiekcie”). Warto dodać, że w niektórych obiektach zlokalizowanych $\mathrm{w}$ Warszawie wprowadzono sezonowe zajęcia z instruktorami, odbywające się w określonych godzinach (www.sportowa.warszawa.pl).

${ }^{5}$ Warto zaznaczyć, że z kolei w czasie badań dotyczących placów zabaw (prowadzonych w tym samym okresie, tj. w latach 2016-2017) opiekunowie dzieci często wskazywali na potrzebę zainstalowania tam przyrządów gimnastycznych dla osób dorosłych, co pozwoliłoby im aktywnie spędzać czas z pociechami. Wydaje się zatem, że place zabaw i siłownie plenerowe powinny być ze sobą sprzężone funkcjonalnie i programowo. Potrzeby mieszkańców znalazły odzwierciedlenie w założeniach Otwartych Stref Aktywności.

${ }^{6}$ Przykładowo w mieście Tainan na Tajwanie w 2012 r. w ciągu 4 miesięcy zamontowano siłownie plenerowe w 86 parkach miejskich, co stanowi 65\% wszystkich parków (CHOW 2013).

${ }^{7} \mathrm{~W}$ niniejszej tabeli nie uwzględniono dwóch obiektów - siłowni plenerowej na terenie Ośrodka Sportu i Rekreacji OSiR przy pływalni "Orka” w Sochaczewie oraz na terenie AWF Warszawa przy ulicy Marymonckiej 34 - z uwagi na ich nietypową lokalizację.

\section{BIBLIOGRAFIA}

BALE J., 2001, Sport, Space and the City, Caldwell, New York. CERVER F., 1992, Sport Facilities, New Architecture Publishing, Madrid.

CHEISURA A., 2004, The role of urban parks for sustainable city, „Landscape and Urban Planning”, 68, 1, s. 129-138.

CHMIELEWSKI M.J., 2002, Urbanistyka, Wyd. Politechniki Warszawskiej, Warszawa. 
CHOW H.-W., 2013, Outdoor fitness equipment in parks: a qualitative study from older adults' perceptions, „BMC Public Health”, 13, 1216, doi: 10.1186/1471-2458-13-1216.

DALY J., 2000, Recreation and Sport. Planning and Design, Human Kinetics, Chicago.

European Commission, 2013, Building a Green Infrastructure for Europe, European Union.

KORZENIEWSKI W., 1989, Budownictwo mieszkaniowe. Poradnik projektanta, Wyd. Arkady, Warszawa.

KOZDROŃ E., 2008, Zorganizowana rekreacja ruchowa kobiet w starszym wieku w środowisku miejskim. Propozycja programu i analiza efektów prozdrowotnych, Akademia Wychowania Fizycznego w Warszawie, Warszawa.

LEE A.C.K., MAHESWARAN R., 2011, The health benefits of urban green spaces: a review of evidence, "Journal of Public Health", 33, 2, s. 212-222, doi: 10.1093/pubmed/fdq068.

LEITNER M.J., 2004, Leisure in later life, Sagamore Publishing, University of Illinois, Urbana.

MAAS J., VERHEIJ R.A., GROENEWEGEN P.P., DE VRIES S., SPREUWENBERG P., 2006, Green space, urbanity and health: how strong is the relation?, "Journal of Epidemiology \& Community Health", 60 (7), s. 587-592, doi: 10.1136/jech.2005.043125).

MOGIŁA-LISOWSKA J., 2010, Rekreacyjna aktywność dorostych Polaków - uwarunkowania i styl uczestnictwa, Akademia Wychowania Fizycznego Warszawa, Warszawa.

MorGUleC-ADAMOWICZ N., KOSMOL A., MOLIK B. (red.), 2015, Adaptowana aktywność fizyczna, Wyd. Lekarskie PZWL, Warszawa.

OSTROWSKI W., 2001, Wprowadzenie do historii budowy miast. Ludzie $i$ środowisko, Wyd. Politechniki Warszawskiej, Warszawa.

PAWLIKOWSKA-PIECHOTKA A., 2014, Europejskie tradycje rekreacji $w$ mieście, Akademia Wychowania Fizycznego Józefa Piłsudskiego w Warszawie, Warszawa.

PIĄTKOWSKA K., SCHOLTZ A., WIRSZYŁŁO R., 1976, Rekreacja $w$ osiedlu, Centralny Ośrodek Badawczo-Projektowy Budownictwa Ogólnego, Warszawa.

RZEGOCIŃSKA-TYŻUK B., 2005, Sport $w$ przestrzeni publicznej wspótczesnego miasta, "Architektura. Czasopismo Techniczne", 1-A, 9, 102, s. 231-256.
RZEGOCIŃSKA-TYŻUK B., 2010, Przestrzeń sportu w miejskim środowisku mieszkaniowym, „Architektura. Czasopismo Techniczne", 1-A (2), 6, 107, s. 109-118.

SAWYER T.H., 2006, Facility Planning and Design for Health, Physical Activity, Recreation and Sport, Sagamore Publishing, Urbana.

SCOTT A., STRIDE V., NeVILLE L., HUA M., 2015, Design and promotion of an outdoor gym for older adults: a collaborative project, „Health Promotion Journal of Australia”, 25, 3, s. 212-214.

STUTZERBACHER P., UlRICH S., 2002, Architecture for Sport, Wiley Academy, New York.

TOŁWIŃSKI T., 1963, Urbanistyka, t. 1-3, Wyd. Politechniki Warszawskiej, Warszawa.

TYSZKA A., 2012, Polskie miasta ogrody w tradycji europejskiej, [w:] Polska tradycja miast ogrodów, Stowarzyszenie Związek Podkowian, Podkowa Leśna.

UJMA-WĄSOWICZ K., 2012, Kształtowanie przestrzeni sportowo-rekreacyjnej w mieście. Ewolucja problemu, Wyd. Politechniki Śląskiej, Gliwice.

VAN DEN BERG A., MAAS J., VERHEIJ R.A., GROENWEGEN P.P., 2010, Green space as a buffer between stressful life events and health, „Social Science and Medicine”, 70, 8 (April), s. 12031210.

WEJCHERT K., 2008, Elementy kompozycji architektonicznej, Wyd. Arkady, Warszawa.

WIRSZYŁŁo R., 1982, Urządzenia Sportowe, Wyd. Arkady, Warszawa.

http://sportowa.warszawa.pl/.

https://app.twojbudzet.um.warszawa.pl.

https://cordis.europa.eu/.

https://weburbanist.com/.

www.bip.msit.gov.pl.

www.fitpark.pl.
Artykuł wpłyną: 27 grudnia $2017 \mathrm{r}$. Zaakceptowano do druku: 26 lutego $2018 \mathrm{r}$. 